\title{
The Transformation and Christianisation of Urban Landscapes in Central Lusitania during Late Antiquity and the Early Middle Ages: the Cases of Ammaia and Ebora Iulia
}

\author{
Emilia Gallo \\ Department of Human Sciences, University of l'Aquila, Italy \\ email: gallo.emilia@libero.it
}

\section{Abstract}

This research focuses on the process of late transformation and final abandonment of Roman towns, on the Christianisation phenomenon and on the late antique evolution of settlement patterns in central Lusitania. The traditional explanations of sudden abandonments of Roman centres, due to "external" events, were swept away by a more scientific approach to archaeological evidence. The article presents data on the Late Antiquity phases of Ammaia and Ebora lulia (today Évora). The results of a long period of archaeo-topographical research on the deserted Roman town of Ammaia (Marvão, Portugal), supported by international scientific collaborations, disclose new scenarios. On the basis of the survey data, integrated with the results of the recent ground-truthing excavations, it is possible to state that, from the beginning of the fourth century AD, the town seemed to be interested in a process of transformation and not of degradation. Évora was a bigger town and it was, from the fourth century AD, the seat of the diocese. In fact, it was one of the first towns of Lusitania and its bishop was present at the Council of Elvira (306/314 AD). Évora, unlike Ammaia, had continuity of occupation and therefore archaeological research has to deal with the problems usually connected with urban archaeology. The intention is to draw a short summary about the transformations that characterise the two towns in this period and, finally, identify common elements and differences.

Keywords: Christianisation, Lusitania, Transformations, Urban Landscapes, Rural Landscapes.
This research, framed by a $\mathrm{PhD}$ project, focuses on the process of late transformation and final abandonment of Roman towns, on the Christianisation phenomenon and on the late antique evolution of settlement patterns in central Lusitania. In fact, the traditional explanations of sudden abandonments of Roman centres, due to 'external' events like natural disasters or barbarian invasions and destructions, were swept away by a more scientific approach to archaeological evidence, which provided a more complex interpretation of historical and economical developments of the Late Antiquity period and to a deeper understanding of the acculturation phenomena.

The results of a long period of archaeo-topographical research on the deserted Roman town of Ammaia (Marvão, Portugal) (fig. 1), supported by an international scientific collaboration (University of Cassino, Italy; Gent University, Belgium and the Universities of Évora and Coimbra, Portugal), disclose new scenarios into understanding the process of late transformation and final abandonment of this Roman town.

Beginning from the fourth century $A D$, the city seemed to be involved in a process of transformation and not of degradation. The new stratigraphical excavations (Corsi, 2014), the extensive geophysical survey (Corsi \& Vermeulen, 2012), the analysis of preserved Late Antique and Medieval structures, investigated with a methodology aimed at "decoding" the complex stratigraphical sequences of infrastructures ("Archaeology of Architecture') (De Minicis \& Gallo, 2014) and the processing of archaeological materials collected during the last fifteen years, have given the opportunity to register a dramatic increase in our 


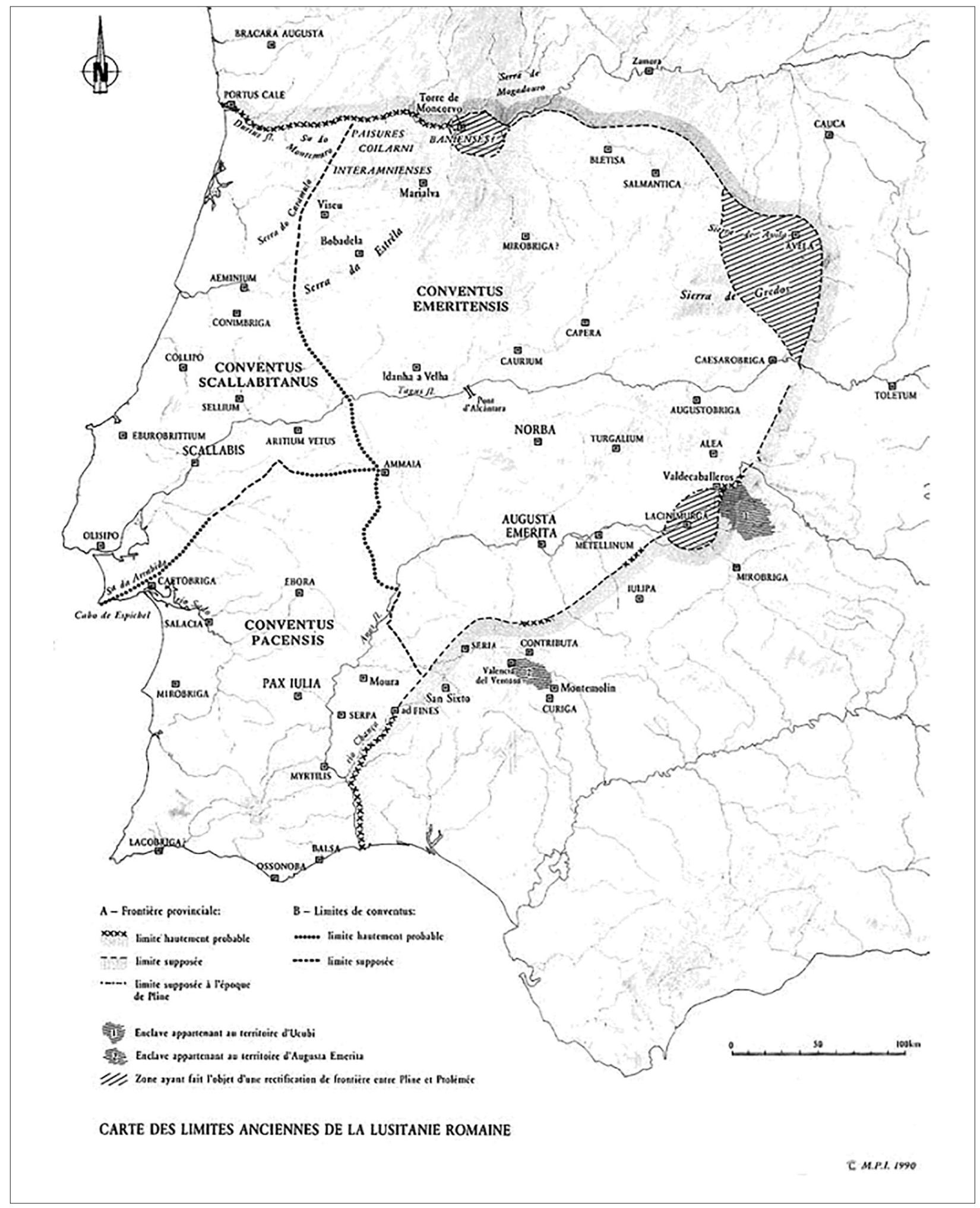

Fig. 1. Ammaia and Ebora Liberalitas lulia in Roman Lusitania (after Mantas, 1998: 33). 


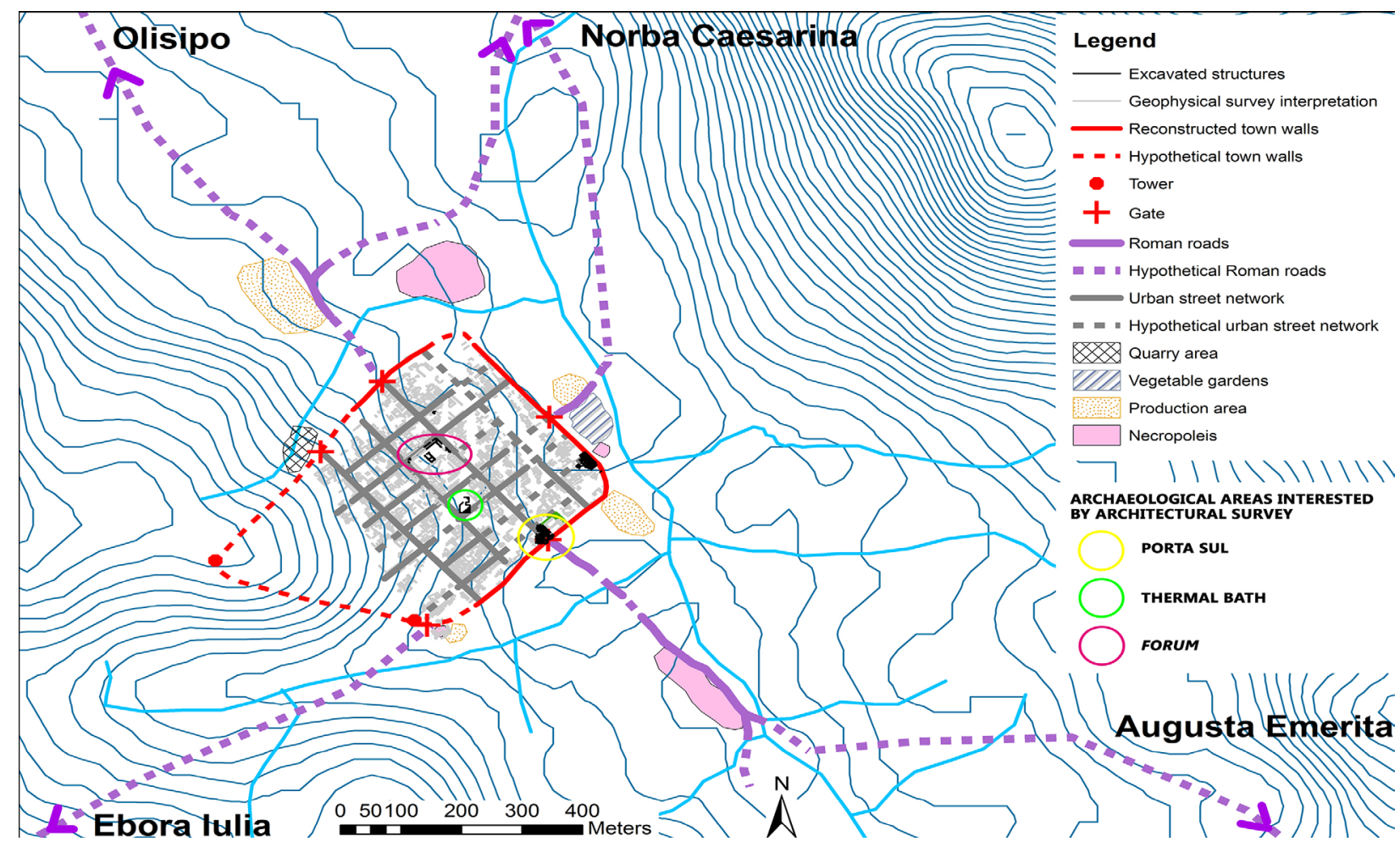

Fig. 2. Ammaia. City and suburbium with location of the archaeological areas interested by architectural survey (elaborated by author after Corsi \& Vermeulen, 2012).

knowledge of the town, its material culture, its economy and its evolution (fig. 2). The architectural survey discloses new scenarios about the development and transformation of urban settlement dynamics during the Late Antiquity period; the study suggests a phase of continuity of city life at the southern gate (Porta Sul) (fig. 3) and a phase of abandonment of the part of town where the forum and the thermal baths were located (De Minicis \& Gallo, 2014) (fig. 2).

After having been analysed individually, the samples were first compared with the other walls belonging to the structures already dated in the city of Ammaia, and then one another. Finally, an analysis of the mortars was carried out (Cardoso et al, 2013). The results of the study of material culture and numismatic findings have already supported this first evaluation. On the basis of the survey data, integrated with the results of the re-

cent ground-truthing excavations, it is logical that during the late fourth century the town started a long process of transformation and not of decline. When looking at indications for the "Christianisation' of the city, we have to admit that at this stage no indication can be signalled. None of the buildings seen through the 'radiography' of the subsoil can be interpreted as a possible Christian basili$\mathrm{ca}$, and thanks to the presence of larger building features with an apse, this type of structure can normally be easily recognised. Instead, the finding of a Christian inscription in the Monte Velho area remains uncertain (Pereira, 2005). It is indeed possible that in this area, as elsewhere documented, rural settlements in the countryside for the construction of Christian worshipping places were preferred, for example the villa of Torre de Palma.

The excavations carried out in the villa of Torre de Palma (Monforte) prove undoubtedly that this huge rural complex, with its basilica and baptistery, played an important role for some rural districts, at least for Christian cults (Maloney, 1995; Ringbom \& Maloney, 2000). This complex had a series of transformations during the course of the 


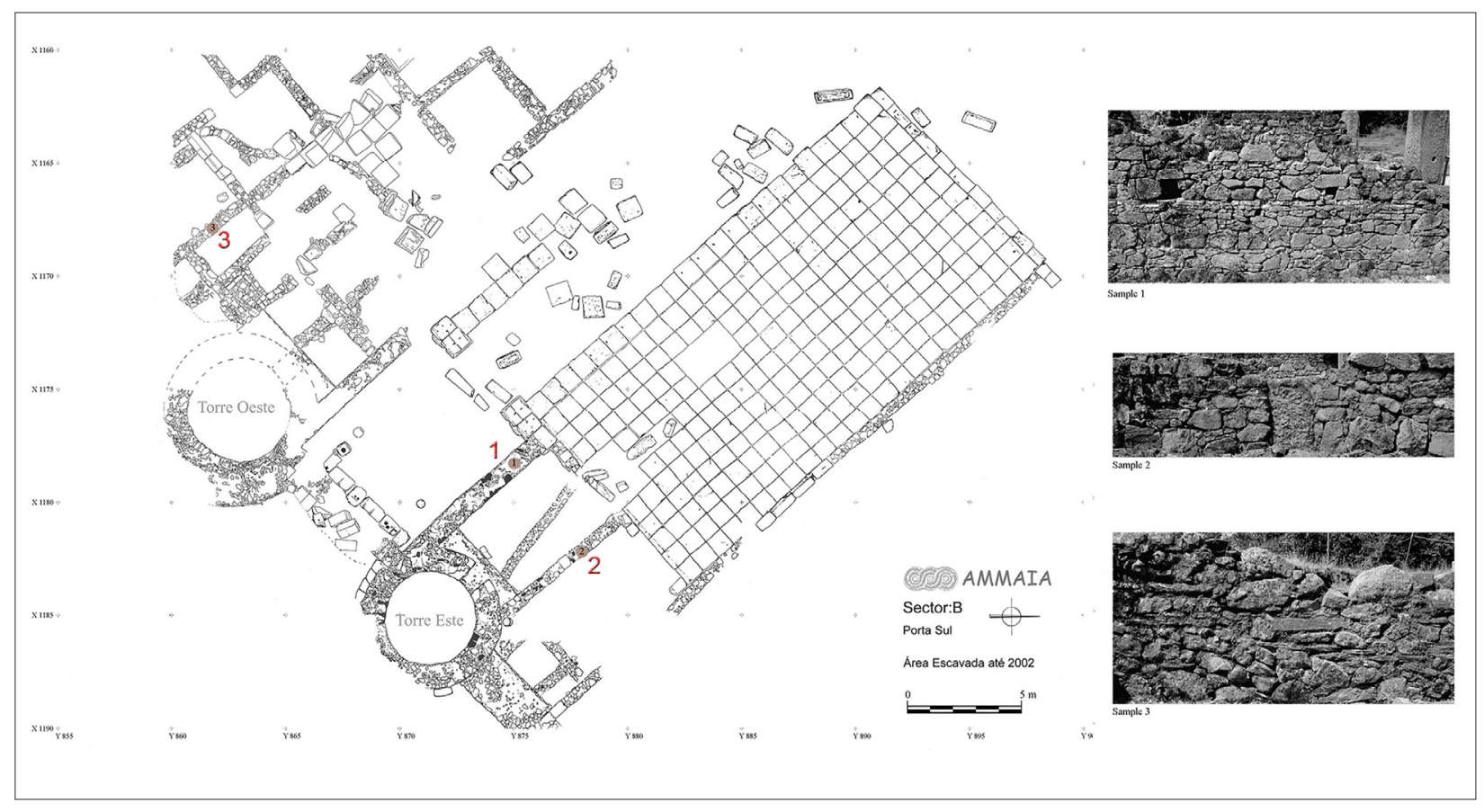

Fig. 3. Ammaia. Archaeological map of Porta Sul with samples of architectural survey (rielaboration by author after Corsi, 2014).

fourth and fifth centuries and can be considered a real parish as it was connected to the practice of a cult, a baptistery and a burial space.

Myrtilis, although it was not an episcopal centre, had an urban Christianisation, whereas Ammaia had a rural one. Geomorphology and economical trends influenced the different evolution of these two cities. The main difference between them was that Ammaia had large villae within its territory but Myrtilis did not.

In this period, the rural world and the villae, in the territory of Ammaia, acquired major centrality. In my opinion, however, the causes of ruralisation could not be identified by the "catastrophic" arrival of foreign troops, but in an economic change, already begun in the fourth century and realised later in the fifth.

The urban identities adapted themselves to new demands: the rural heritage ensured greater economic sustainability, certainly in the Northern Alentejo, which became an attractive centre for those populations who lived in difficult urban conditions. During the Late Antiquity period, cities were subjected to changes which were included into the phenomenon of 'urban isostasy'. The latter can be described as the 'equilibrium' in the demographic figures and the evenness in the distribution of activities among cities, suburbs and the territory.

To sum up, we have reasons to think that the city of Ammaia did not collapse at the end of the fifth century, but continued to live: some areas of the city had disappeared but the suburb and the territory were now ready to welcome the populations from the town in their rural villae.

Évora (fig. 1) was a bigger town and it was the seat of the diocese from the fourth century AD. Évora, unlike Ammaia, had continuity of occupation and therefore archaeological research has to deal with the problems usually connected with urban archaeology.

In various contexts the importance of Évora in Roman times continued into Late Antiquity: late Roman, Germanic and Visigothic periods. This centrality lasted and increased, although this process may seem senseless, if we keep in mind the fact that this city suffered, as others Lusitanian cities did during the transition from the third to the fourth century. This was due to a restriction on 
their urban development with the building around the city of protective walls against barbarian invasions (figs. 4, 5) (Val-Flores, 2004). Effectively, the small amount of information that is available is enough to assume the intensity of social, economic and artistic relations occurring throughout the fourth century in the territory of Évora, adding a new stance to the city, fundamentally for the role it would play during the visigothic domination: that of the episcopal 'headquarters'.

The results of the study of material culture gave evidence of the changing ideologies where Christianity left ineffaceable marks. Quintianus, bishop of Évora, one of the most ancient episcopal centres of the Iberian Peninsula, signed the Actas do Concilio de Elvira (AD 306/314) (Jorge, 2002).

The cult of the martyrs, one of the more dynamic aspects of Christianity during the Late Antiquity, was also present in Évora. This could be noted from a narrative included in the Passio of São Mancio or Mancios which stretched back to the seventh century but which was also indirectly witnessed by the study of place names and by the dedication of the parishes and churches towards the first martyrs, particularly in the countryside (Fernández Catón, 1983).

It is important to make reference to some of the more valuable material traces from the Christianisation of the territory of Évora, technically its countryside, providing evidence that enabled the Germanic/Visigothic perspective from which the Byzantine evidently emerged, making the relationship with a possible occupation in the south of Lusitania by the Byzantine troops in the beginning of the seventh century obvious.

The analysis of the excavation's reports, obtained thanks to the collaboration with the Regional Direction of Culture of Alentejo, in Évora, allowed me to get important information concerning the investigated period. Also the excavation at the Roman temple provided essential information.

In the cryptoporticus area, a large number of ceramic fragments belonging to medieval phases were discovered, leaving a supposition of a reoccupation of private housing, probably dating at the time of the reconquest. These data show an abandonment of the area which had already happened during the Late Antiquity and the Early Middle Ages.

In 1990, during the excavations, small architectural fragments were found under the pavement of the square, in the layers preserved in the original stratigraphic sequence. These pieces were dated by $T$. Hauschild to the Visigothic period. Fragments of pots and a bowl were found in the same excavation. They were similar to those from the Visigothic layers of the excavation in Cancho of Confesionario (Madrid) and Recópolis (Guadalajara).

In 1995, during the campaign of excavations, made again near the Roman temple, a well preserved marble sima was found in a silo. This was an interesting discovery, because, until then, whole pieces of architectural decoration belonging to the Visigoth period were never discovered in Évora. This place of discovery corresponded to a silo located approximately $10 \mathrm{~m}$ north of the Roman temple, filled with earth, stones and fragments, from a second phase. According to the study of the ceramic fragments, its contents can be dated back to the late Islamic period, that is, between the eleventh and thirteenth centuries.

According to $G$. Maciel this finding belongs to an architectural liturgical context: more precisely, he supposed that this "sima" belonged to a religious building located in the vicinity of the forum of the city (Hauschild, 1996). This assumption was based on the comparison with the "sima" localised in the baptistery and in the apse of the basilica of Casa Herrera, near Mérida (Hauschild, 1996).

In my opinion, the analysis of unpublished reports of excavations made between 1996 and 1998 in the area of the museum of Évora, could confirm this hypothesis. I contend that the presence of a Visigoth church is possible in the vicinity of the area investigated by the excavations. The identification of a marble slab with Visigoth decorations and the presence of lateral grooves typical of a gate of the period, along with the discovery of the "sima" in the ruins of the temple and the identification of abundant pottery fragments belonging to the late Roman and Visigoth period, support my 


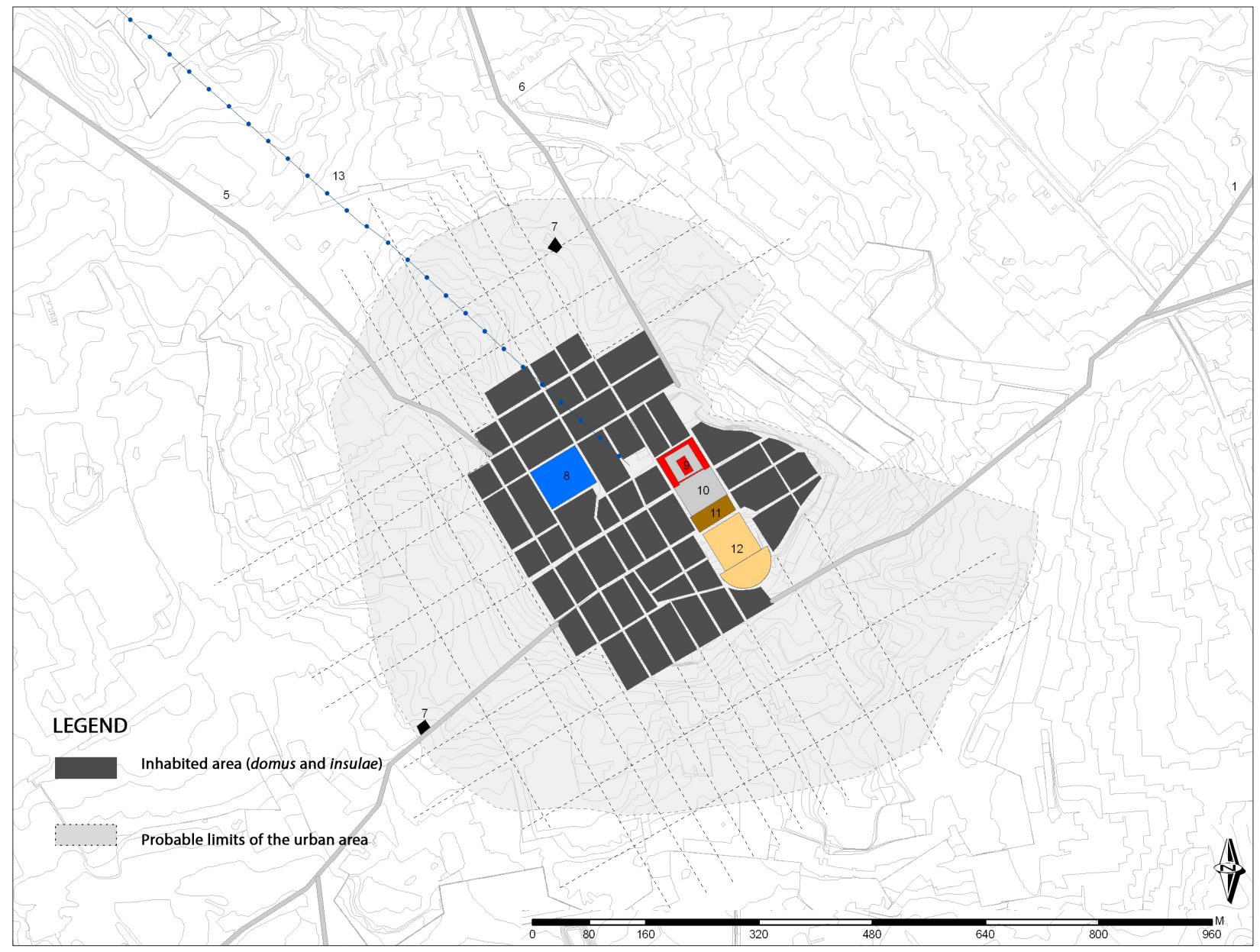

Fig. 4. Ebora Liberalitas Iulia. Map of town and suburbium during the first century AD (elaboration by author after Val-Flores, 2004).

hypothesis. In the museum there is also a marble pillar of the seventh century unmentioned in the examined excavation reports. Finally, I would like to underline, that we are in one of the oldest cities of Lusitania, the seat of the diocese. For this reason we can suppose that Évora had a cathedral, whose location was probably in the ancient Roman forum reoccupied in the Late Antiquity period. Further surveys would be necessary to confirm this hypothesis.

In conclusion, the urban model based on the city-countryside interaction gives, in time, a true and solid stance to the daily life of the countryside (fig. 5). The fact that Évora was the capital of a civi-

tas and that the bishop established his seat there, surely influenced the Late Antique development: for these reasons it conserved its power through the centuries, while Ammaia was completely destroyed in the Early Middle Ages. 


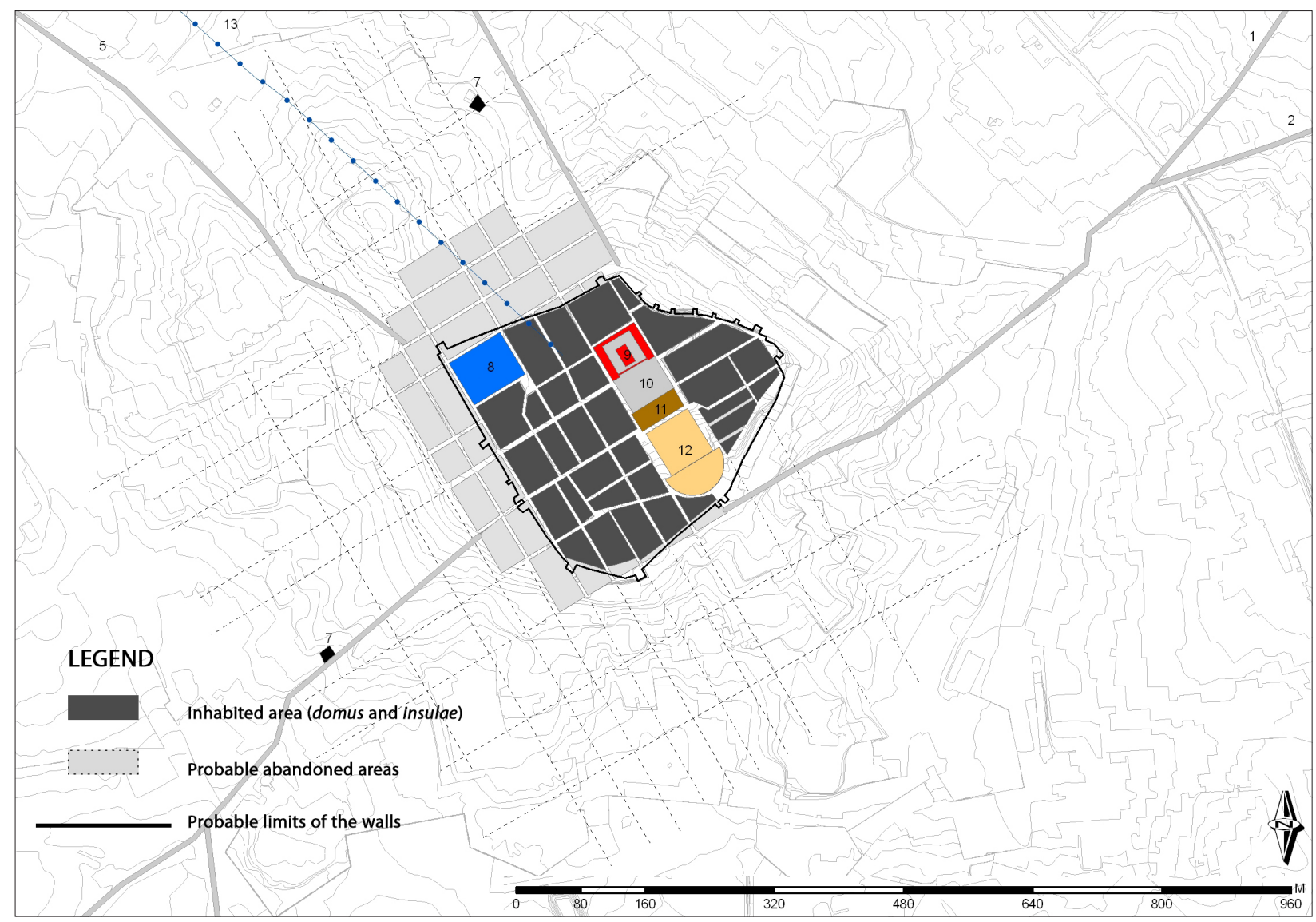

Fig. 5. Ebora Liberalitas Iulia. Map of city and suburbium during the fourth century AD lelaboration by author after Val-Flores, 2004).

\section{References}

Cardoso I, Macedo MF, Vermeulen F, Corsi C, Santos Silva A, Rosado L, Candeias A \& Mirao J 2013: A Multidisciplinary Approach to the Study of Archaeological Mortars from the Town of Ammaia in the Roman Province of Lusitania (Portugal), Archaeometry, doi: 10.1111/arcm.12020, vol. 55, issue 2, 179-354.

Corsi C, 2014: Ammaia II: The excavation contexts 19942011, Academia Press, Ghent.

Corsi C \& Vermeulen F (ed.) 2012: Ammaia I: the survey. A Romano-Lusitanian townscape revealed, Academia Press, Ghent.

De Minicis E \& Gallo E 2014: Structural analysis of sample masonry, in Corsi C (ed.), Ammaia II: The
Excavation Contexts 1994-2011: 263-74. Academia Press, Ghent.

Fernández Catón JM, 1983: San Mancio: Culto, leyenda y reliquias. Ensayo de crítica hagiográfica, Centro de Estudios y Investigación San Isidoro, León.

Hauschild T, 1996: Évora, un cimacio da época visigotica encontrado junto ao templo romano, in “Miscellanea" in Homenagem ao professor Bairrão Oleiro: 271-74. Colibri, Lisboa.

Jorge AM, 2002: L'épiscopate de Lusitanie pendant l'Antiquité tardive (III-VII siécles), Instituto Português de Arqueologia, Lisboa.

Maloney SJ, 1995: The early Christian basilican complex of Torre de Palma (Monforte, Alto Alentejo, Portugal), in IV Reunió d'Arqueologia Cristiana Hispànica: Lisboa, 28-30 de setembre, 1-2 octubre de $1992=$ IV Reunião de Arqueologia Cristã Hispânica: Lisboa, 28-30 setembro/ 1-2 outubro 1992: 449-58. Institut d'Estudis Catalans, Barcelona.

Mantas VG, 1998: Colonização e aculturação no Alentejo Romano, Arqueologia de Beja, 3(7-8), 33-61. 
Pereira S, 2005: Da Desagregação do Império ao Período Visigótico na Freguesia de S. S. da Aramenha, in de Oliveira J (ed.), São Salvador da Aramenha. História e Memórias da Freguesia (Ibn Maruán. Revista cultural do Concelho de Marvão 13): 63-71. Colibrì, Lisboa.

Ringbom A \& Maloney SJ, 2000: 14C dating of mortars at Torre de Palma, Portugal, in V Reunió d'Arqueología Cristiana Hispánica, Cartagena (1998): 151-55. Institut d'Estudis Catalans, Barcelona.

Val-Flores GS, 2004: A Evolução Urbana do Centro Histórico de Évora, vol. 1, Ebora Liberalitas Iulia, Câmara Municipal de Évora, DCHPC, Évora. 